\title{
Net zero 2050 as an EU priroty: modeling a system for efficient investments in eco innovation for climate change mitigation
}

\author{
Jelena Jesic ${ }^{1^{*}}\left(\mathbb{D}\right.$, Andrea Okanovic ${ }^{2}(\mathbb{D})$ and Andrea Andrejevic Panic ${ }^{1}$ (D)
}

\begin{abstract}
Background: The study background is based on the fact that The Recovery Plan for Europe envisages investing 30\% of the huge budget in climate change, with the goal of zero gas emission by 2050. This ambitious plan will require (for now indefinitely) investments in research and innovation. The study's main objective is to check and analyze the existing and propose a new model of effective investments in eco-innovation. This will contribute to effective long-term investment policy, climate change impact, and mitigation of consequences.

Methods: The basic methodological tools for solving the problems discussed in this study were correlation analysis, regression analysis, and paired sample t-test. All calculations were performed in the SPSS 20 statistical software. Time series data of the selected indicators were obtained from the European Innovation Scoreboard 2020. The database used to collect the data for the EU member countries and selected third countries for the analysis is the European Innovation Scoreboard 2020. To avoid sample selection bias, the authors considered all of the available data for all the member countries and selected third countries in the European Innovation Scoreboard 2020 for the 2012 to 2019 period.
\end{abstract}

Results: The study results show the path developing countries should follow in directing their inevitable and increasing eco-innovation investments, taking into account the arguments of structural differences in financing Research and Development (R\&D). The authors' findings support the thesis that investments in R\&D is low in developing countries, while in developed EU countries, there are more investments in R\&D from the business sector for the 2012-2019 period.

Conclusions: Study conclusions are summarized as a proposal of the appropriate R\&D financing model approach to developing countries with a greater share of eco-innovation and self-sustainable R\&D financing for climate preserving products. This study is important as it provides new evidence on financing R\&D investments in innovation leader countries and emerging innovator countries according to Summary Innovation Index.

Keywords: Summary innovation index, Eco-innovations, Sustainable R\&D financing, Knowledge management, EU, Developing countries, Net zero

*Correspondence: jelena.jessic@educons.edurs

${ }^{1}$ Faculty of Business Economics, University Educons, Vojvode Putnika 87, Sremska Kamenica, Republic of Serbia

Full list of author information is available at the end of the article

\section{Background}

The Recovery Plan for Europe envisages investing 30\% of the huge budget in climate change, with the goal of zero gas emission by 2050. This ambitious plan will require (for now indefinitely) investments in research and innovation. The paper aims to check and anatomize the existing and propose a new model of effective original author(s) and the source, provide a link to the Creative Commons licence, and indicate if changes were made. The images or other third party material in this article are included in the article's Creative Commons licence, unless indicated otherwise in a credit line to the material. If material is not included in the article's Creative Commons licence and your intended use is not permitted by statutory regulation or exceeds the permitted use, you will need to obtain permission directly from the copyright holder. To view a copy of this licence, visit http://creativecommons.org/licenses/by/4.0/. The Creative Commons Public Domain Dedication waiver (http://creativeco mmons.org/publicdomain/zero/1.0/) applies to the data made available in this article, unless otherwise stated in a credit line to the data. 
investments in eco-innovation. This will contribute to effective long-term investment policy, climate change impact, and mitigation of consequences.

More than $50 \%$ of the amount in the Recovery Plan for EU will support modernisation, for example, through research and innovation, via Horizon Europe, fair climate and digital transitions, via the Just Transition Fund and the Digital Europe Programme, preparedness, recovery and resilience, via the Recovery and Resilience Facility, rescEU and a new health programme, EU4Health. In addition, the package pays attention to modernising traditional policies such as cohesion and the common agricultural policy, to maximise their contribution to the Union's priorities fighting climate change, with $30 \%$ of the EU funds, the highest share ever of the European budget, biodiversity protection and gender equality.

The General Recovery Plan and Innovation Policies for EU countries underline the importance of coordination between strategies and investments when it comes to the digital and green transitions. There are many challenges in setting up innovation policies, such as applying the right role of EU energy efficiency policy in a multi-level governance structure; the lack of institutionalisation; better policy evaluations; more understanding of real-world policy mixes; and a socio-technical approach to energy efficiency [1]. Its crucial roles for the implementation of Europe's policy objectives are the following: Partnerships and Missions under Horizon Europe will play the role of cohesion and coordination between the Member States, the priorities should enhance the competitive role of the EU in the global scene, the centrality of R\&D in building the EU's resilience, as well as the need for better coordination and synergies among programmes to ensure Europe's digital and green competitiveness. Also, the policy must define where we want to go and what is the best way to get there. From this point of view, we can explain the importance of measuring innovation competitiveness on different levels [2]. Rules of public authorities and governmental bodies can regulate innovation policies in three ways: economic regulation includes competition policies, price regulation, market entry regulations, regulation of natural monopolies; social regulation addresses the impact of environmental regulation and safety regulations mainly in the health sector; and institutional regulation which represents administrative regulations [3]. As authors Nasierowski and Arcelus [4] underline-if the impact of contextual elements upon the level of innovativeness is isolated, a composite index could serve as a starting point to examine the effectiveness of programs oriented toward supporting innovativeness (i.e., to which extent policies related to innovativeness indeed contribute to social and economic objectives).
The Summary Innovation Index is an established mechanism and tool for measuring global, national, and regional innovation systems. This indicator is suitable for measuring the increasing impact on environmental and social spheres and systematic R\&D financing. The Summary Innovation Index is an important part of the EU Innovation Agenda and Recovery Plan for EU, as well as a tool for developing countries to structure their funds for financing R\&D, following the best and most successful examples for financing structures and models.

The European Innovation Scoreboard (EIS) is an important tool for measuring innovation performance using a composite indicator-the Summary Innovation Index-which is constructed of a range of different indicators. The Summary Innovation Index includes 27 indicators arranged in several groups: framework conditions, Investments, Innovation activities, and Impacts-and ten innovation dimensions. EIS provides a comparative assessment of the research and innovation performance of the EU Member States and enlargement countries. This report helps countries focus on areas in which they need to put more effort and boost their innovation performance [5].

The Eco-Innovation Scoreboard and the Eco-innovation Index complement other measurement approaches of innovativeness of EU countries and aim to promote a holistic view on economic, environmental and social performance. Great efforts across the EU Member States are being made to construct and measure the Eco-Innovation Scoreboard (Eco-IS) and the Eco-Innovation Index to illustrate eco-innovation performances. The aim is to acquire the different aspects of eco-innovation by applying 16 indicators grouped into five dimensions: ecoinnovation inputs, eco-innovation activities, eco-innovation outputs, resource efficiency and socio-economic outcomes. The final score is calculated by the unweighted mean of the 16 sub-indicators [6], it also shows how individual countries perform compared to the EU average, which is equated with 100 (index $E U=100$ ), and this index is part of the Eco-Innovation Scoreboard (Eco-IS). The main achievement of the Eco-Innovation Index is the possibility to detect how well individual Member States perform in different dimensions of eco-innovation compared to the EU average and present their strengths and weaknesses.

A very important process for developing countries is identifying structural differences in financing the $R \& D$ between Innovation leaders, Strong Innovators, Moderate and Modest Innovators countries. Indicators that significantly, directly or indirectly, affect the achieved level of innovation of individual countries are precisely determined by the Summary Innovation Index, European Innovation Scoreboard, Eco-Innovation Scoreboard, etc. 
The indicators were selected based on a particular economic theory and logical interpretation of the influence of financing from different institutions on the Country Performance according to the European Innovation Scoreboard. The complementary objective of this work is to compare these dependencies between selected indicators and suggested contextual indicator values within the Member States and selected third countries. Relying upon fact-based reports, which also explore the extent to which the differences in the countries' scores in the European Innovation Scoreboard (EIS) can be explained by various socio-economic, demographic, cultural and other factors, this analysis finds that Innovation leaders use more financing of $R \& D$ from the business sector. Interesting results emerged when the sample was divided into two groups: the group mostly financed from the public sector and the group mostly financed from the business sector. The results show that structural differences in R\&D financing influence countries' performance presented in the European Innovation Scoreboard. Innovation Leaders have predominantly financed the characteristics of R\&D from the business sector, while Moderate and Modest Innovators' actions are significantly lower in business and public funds for financing R\&D investments. Countries with the highest $R \& D$ spending do not necessarily achieve the best innovative results. It is worth mentioning that international organisations are currently working on more sufficient innovation input statistics such as stock of current knowledge, number of innovative enterprises, R\&D expenditures, human resources and research infrastructures, which can provide a more upto-date picture of efficiency [7]. The analysis of authors Anderson and Stejskal [8] reveals that structural and financial capacity alone does not connote a higher efficiency of innovation of diffusion even as it is desperately needed as a necessity for diffusion of innovation. Global innovation trends and the innovation performance of 131 economies are presented in the Global Innovation Index 2020. In addition to significant data and fostering innovation debates and policies-a clear question of this year's edition of the Global Innovation Index 2020 is: Who Will Finance Innovation? This endeavour and striving to make the best ratio of investments and results in research and development are more than necessary, especially in terms of searching for sustainable products and services that will be less harmful to the natural environment. Today sustainability governance systems must continue to develop, make improvements and be flexible to meet identified challenges and make progress towards more sustainable societies [9]. Innovation is fundamental for making sustainability possible and improving efficiency. Yet, innovation for sustainability must be environmentally friendly (e.g., green technologies) [10].
The transition to a climate-neutral, climate-resilient and environmentally sustainable economy will require significant investments. Achieving existing climate and energy targets for 2030 requires additional investments of $€ 260$ billion per year. This figure mainly includes investments related to energy, buildings, and part of the transport sector (vehicles). The average investment needing by sectors are highest in the area of building renovation. It is necessary to maintain the continuity of these investment flows. Significant resources will also be needed in other sectors, notably agriculture, to address wider environmental challenges, including biodiversity loss and pollution, protection of natural capital and support for the circular and blue economy, and human capital and transition-related social investments.

Digitisation is a key driving force of the green plan. Significant investments in Europe's strategic digital capacities and the development and extensive introduction of state-of-the-art digital technologies will create the preconditions for smart, innovative, and tailor-made solutions to address climate issues.

Due to the planned increase in the EU's target for reducing greenhouse gas emissions by 2030, as announced in The European Green Plan, investment needs will increase further. A detailed analysis supporting the Commission's long-term strategic vision for the EU's climate-neutral economy has already suggested that the transformation to a low-carbon economy could require an additional investment of up to $2 \%$ of GDP by 2040. This deadline may need to be shortened in order for a higher level of ambition to be achieved by 2030 . Under the Investment Plan for a Sustainable Europe, the investment components of the European Green Plan, sustainable investments of at least EUR 1 trillion will be mobilized in the next decade. This amount of funding for the green transition will come from allocations from the EU's long-term budget, a quarter of which for climate change and an estimated $€ 39$ billion for environmental expenditure. In addition, the Plan will attract additional private investment thanks to the effect of the EU budget guarantee under the InvestEU program.

According to the Investment Plan for a Sustainable Europe, which anticipates EU expenditure directed to climate action and environmental policy, it additionally includes amounts and measures for the Fair Transition Mechanism to support the most damaged transition regions. Furthermore, the European Investment Bank announced the plan to gradually increase its share of funding for climate action and environmental sustainability to $50 \%$ of total operations in 2025. By acting towards climate change prevention financing, it will transform to the Climate Union Bank. This contribution demonstrates the EU's commitment to funding the 
European Green Agenda. Still, it must engage the other financial stakeholders because the European Investment Bank alone will not be enough to mobilize the necessary investments. Significant contributions will be needed from both national budgets and the private sector.

According to Gsodam et al. [11], key resources are renewable energy plants, which are usually smaller than conventional power plants but are quite similar to them in terms of value creation. A new tariff for green electricity can increase revenues, as the revenue model reflects costs that arise from planning, construction, operation, maintenance and revenues arising from charging the customer for the amount of electricity delivered.

In different periods of growth, stagnation, or decline of economic development, even before, during, or after the crisis, a range of new factors, such as venture capitalists, investment funds, biomedical research organisations, sovereign wealth funds, and not-for-profit organizations, have been interested in supporting innovation. However, the innovative process is complex and uncertain even for the experienced and accomplished financial institutions and mechanisms, whether private or public funds [12]. The World Intellectual Property Organization (WIPO) asserts that even after the crisis, innovation mechanisms such as corporate venturing, intellectual property (IP) marketplaces, crowdfunding, and fintech solutions will not vanish. At the same time, public support schemes remain essential drivers of innovation financing. Another important source of information related to the innovation index at national and regional levels is the European Innovation Scoreboard, which compares innovation performance in EU countries, other European countries, and regional neighbours. It assesses national innovation systems' relative strengths and weaknesses and helps countries identify areas they need to address. The latest European Innovation Scoreboard 2020 was released on June 23, 2020. Based on the previous 2012-2019 period and collected relevant data, the main question in this analysis is both the extent to which financing of $R \& D$ from the business sector has influenced the success of the national Summary Innovation Index according to the European Innovation Scoreboard (EIS) and what the role of public investments in R\&D in developed and developing countries is. Competitiveness indices have been monitored for about 40 years and show the rankings of economies by the current factors defining competitiveness. A review of the relevant literature found a separate group of indices that measure the competitiveness of economic innovation.

According to Conway's [13] and Demirel's and Kesidou's study [14], the achieved results indicate that regulation is effective in stimulating end-of-pipe solutions to eco-innovations (so-called 'quick-fixes' to environmental emissions, for example). On the other hand, environmental R\&D and internal drivers, such as efficiency, were more responsible for increased investments in cleaner production technologies through equipment upgrades, which indicates a longer-term view, requiring more financial investments and organisational support.

Since the adoption of the Lisbon Strategy in 2000, innovation has received more and more attention in the European Union. Therefore, it is important to evaluate the current level of the European Union Member States' technological and economic development and their innovations' impact on it. As author Okanovic [15] has also comprehensively described in previous research, these indices bring innovative changes to the environment and include factors such as human resources, intellectual property, research systems, networking, sources of funding for innovation, etc. This group includes The Global Innovation Index, published by the Confederation of the Indian Industry along with INSEAD (since 2008) and also The European Innovation Scoreboard (see a study published by the European Commission, since 2010) and comparison of the EU and US Innovations and competitiveness, as published in a study by The Information Technology and Innovation Foundation (since 2006) as well as The Global Cleantech Innovation Index, published by the Cleantech Group and WWF (since 2012). Likewise it includes The Global Innovation Policy Index, as published by the Information Technology and Innovation Foundation and the Kauffman Foundation (since 2012) and also The Regional Innovation Scoreboard, as published in a study by the European Commission (since 2010) and last but not least, The Innovation Cities Index, as published by the Global Innovation Agency 2thinknow (since 2007). Furthermore, eco-innovations are at the heart of European policies. Therefore, every effort must be made to ensure that developing countries catch up and raise awareness of the necessity of investing and supporting eco-innovation programmes.

Economic development conditioned by innovation impact was evaluated by correlating various composite indices and innovation outputs using the GDP per capita indicator [16]. European Union strategies continue to actively foster and nurture innovation through different modalities, visions, and policy goals for EU research and innovation. Three main sets of innovations and programs, such as open innovation, open science, and open to the world strategies on R\&D in the EU, are still very strong and based on many current policy initiatives and practices. Taking a step further to contribute to the research and innovation strategy, the European Commission set a new goal, through the European Green Deal, to become the world's first climate-neutral continent by 2050 . This ambitious but achievable goal is an opportunity to 
modernise the EU's economy and society and direct them towards a sustainable future. The EU's next research and innovation programme starting in 2021 as a powerful instrument and innovative governance will drive the necessary systemic changes to reach climate neutrality and ensure an inclusive ecological and economic transition. In synergy with other EU programmes, Horizon Europe will be key to leveraging national public and private investment. Through green partnerships, there will be a new wave of research and innovation partnerships under Horizon Europe. Partnerships will help drive huge transformations in the environment, society, and the economy the European Green Deal calls for. The EU will work closely with industry and countries to support partnerships in critical areas such as transport-including batteries-clean hydrogen, low-carbon steel, circular biobased sectors, the built environment, and biodiversity.

Anatomising the current impact of R\&D funding from private and public funds, compared with the results of the goals and trends of developed countries, the authors could suggest how to construct future $R \& D$ investments in developing countries. Differences in economic structures are crucial. In particular, differences in the manufacturing industry share in the GDP and in the so-called high-tech activities in manufacturing and services are important factors that explain why countries can perform better or worse when using indicators such as business R\&D expenditures, PCT patents, and innovative enterprises. Medium-high and high-tech industries have higher technological intensities than other industries. These industries, on average, will have higher $R \& D$ expenditures, more patent applications, and higher shares of innovating enterprises. Countries with above-average shares of these industries are expected to perform better regarding several EIS indicators. For example, for the EU27, on average, $85 \%$ of R\&D expenditures in manufacturing ([17], p. 10) are accounted for by medium-high and high-technology manufacturing industries. Also, the share of enterprises that introduced a product and/ or process innovation is higher in medium-high and high-technology manufacturing industries compared to all core industries covered in the Community Innovation Survey.

The term structural indicators is used (e.g., by Eurostat) to refer to statistical indicators used for a quantitative comparison of performances of territories in selected fields. Furceri and Mourougane [18] point out that such indicators can be both 'perception-based' and 'fact- based'. Both types of indicators have specific advantages and disadvantages. The annual EIS provides a comparative assessment of the research and innovation performance of the EU Member States and selected third countries and the relative strengths and weaknesses of their research and innovation systems. It helps countries assess areas where they need to concentrate their efforts to boost their innovation performance ([17], p. 8). It is of great importance to measure the degree of achievement of the set strategies and monitor and control the set objectives of the strategies. The aim and the basic problem in such actions is the selection of appropriate indicators [19].

In previous studies [20], many researchers highlighted the problems related to regional disparities. Although the European Union has set ambitious goals regarding innovation policies and $R \& D$, there are still problems in achieving the set goal of R\&D representing $3 \%$ of the GDP. Regional disparities have increased over time as well. An objective analysis of achievements and shortfalls is needed to realise the required policy changes within a country level on time.

In the XX century, most of the economic growth theories have been based on innovation-generating processes focusing on the role of productivity, technology change, and knowledge, as well as on the role of the contributing actors. For example, in the Neoclassical Growth Theory, as developed by Solow [21] and his followers, economic growth in the long run results from the combination of capital, labour and technological progress (accounted as an exogenous element) within the industrial sphere. Years later, the so-called New or Endogenous Growth Theory proposed by Romer [22] and Lucas [23] introduced the "shift from a resource-based economy to a knowledgebased economy. It underscores the point that the economic processes which create and diffuse new knowledge are critical to shaping the growth of nations, communities and individual firms" [24]. According to Romer [22], "under the new system, firms will increasingly take advantage of each person's innate curiosity and willingness to experiment...every worker in an organization, from top to bottom, can become a "knowledge" worker if given the opportunity to do so".

Cavallini et al. [25] emphasize that both the Triple Helix $(\mathrm{TH})$ concept and the Quadruple Helix $(\mathrm{QH})$ approach are based on the idea that innovation is the outcome of an interactive process involving different spheres of actors, each contributing according to its 'institutional' function in the society. Traditional protagonists of the $\mathrm{TH}$ are University (UNI), Industry (IND), and Government (GOV). Civil society (CIV) is the additional sphere included in the $\mathrm{QH}$.

Author Ilina [26] asked whether more of qualitative factors in fostering innovation competitiveness of moderate and modest countries could be expected. The problem of competitive sustainability ensuring in the case of the R\&D sector is multidimensional. On the one hand, there is a lack of public funding and support for R\&D; 
on the other hand, there is a lack of effective communication between science and the real sector of the economy, ensuring the effectiveness in the usage of R\&D in practice. In high-income countries, during the last century, the share of knowledge work in total employment increased from close to nil percent to about twenty percent [27]. On the other hand, emerging economies commonly rely upon their resources exportation or importation of production processes which damage the environment [28].

The state's role is complementary to the private sector but still more fundamental due to its capacity to mobilise national resources and its capability to encourage innovations or whole new sectors when the market is unsuccessful in doing that [29]. Lundvall et al. ([30], p. 227) emphasise strategies at the national level, underlining the need to coordinate various policy areas to support the development of innovations. As is the case with some post-socialist economies, governance capacities may not be supportive enough of smart specialisation strategies to really stimulate growth through innovations ([31], p. 169).

The idea of the paper is to examine the impact of business and public funding on the Summary Innovation Index positioning in the EU and selected third countries, the extent to which available resources are well distributed, which countries had a better investment and results ratio. Also, the authors discuss and conclude with the results as to which impact has led to better results in certain countries.

\section{Methods}

The research sample includes the EU Member States, which fall into four performance groups: (1) Innovation Leaders where performance is above $125 \%$ of the EU average; (2) Strong Innovators, with performance between 95 and $125 \%$ of the EU average; (3) Moderate Innovators, where performance is between 50 and $95 \%$ of the EU average; (4) Modest Innovators, showing a performance level below $50 \%$ of the EU average. The basic methodological tools for the solution of the problems discussed in this study were correlation analysis, regression analysis and paired sample $t$-test. All calculations were performed using the SPSS 20 statistical software. Time series data of the selected indicators were obtained from the European Innovation Scoreboard 2020. A correlation analysis was used to examine the association between the three parameters in the overall Summary Innovation Index-R\&D expenditures in the public sector, business sector and public-private co-publications for the period from 2012 to 2019. A paired sample t-test was used to examine the differences in relation to the dominant sector of investments in innovation. Finally, regression analysis was applied to predict the Summary Innovation Index based on independent variables (investments in the public and business sectors).

The observed indicators were selected to point out how many investments in R\&D from the private and public sector in developed and developing countries influence the performance and the result of the Summary Innovation Index ranking. For developed countries, the authors used the first ten countries with the highest Summary Innovation Index. The countries with the highest Summary Innovation Index are Switzerland, Sweden, Finland, Denmark, the Netherlands, Luxembourg, Belgium, Great Britain, Norway, and Germany. For developing countries, the authors used countries with the lowest Summary Innovation Index: Ukraine, Romania, Montenegro, Macedonia, Bulgaria, Croatia, Poland, Serbia, Turkey, Latvia, Slovakia, and Hungary.

The database used to collect the data for EU member countries and selected third countries for the conducted analysis is the European Innovation Scoreboard 2020. To avoid sample selection bias, the paper considered all of the available data for all member countries and selected third countries in the European Innovation Scoreboard 2020 for the 2012 to 2019 period. Descriptive statistics have already been used in the evaluation and processing-they are used to describe the sample and, in this case, to describe the difference between each parameter for each country, which has already been presented in European Innovation Scoreboard 2020.

\section{Results}

The research sample includes the EU Member States, which fall into four performance groups: (1) Innovation Leaders where performance is above $125 \%$ of the EU average (for 2020 include 5 Member States-Denmark, Finland, Luxembourg, The Netherlands and Sweden); (2) Strong Innovators, with performance between 95 and 125\% of the EU average (for 2020 include $7 \mathrm{Mem}$ ber States. Austria, Belgium, Estonia, France, Germany, Ireland, and Portugal); (3) Moderate Innovators, where performance is between 50 and $95 \%$ of the EU average (for 2020 include 13 Member States: Croatia, Cyprus, Czechia, Greece, Hungary, Italy, Latvia, Lithuania, Malta, Poland, Slovakia, Slovenia and Spain); 4. Modest Innovators, showing a performance level below $50 \%$ of the EU average (for 2020, two Member States: Bulgaria and Romania are included).

Correlation analysis was used to examine whether there is a significant relationship between the overall Summary Innovation Index with $R \& D$ expenditures in the public sector, business sector, and public-private copublications for the period from 2012 to 2019. 
Table 1 Correlation coefficients between the summary innovation index and R\&D financing by the public and business sector

\begin{tabular}{ll}
\hline Variable & $\begin{array}{l}\text { Summary innovation index } \\
\text { Correlation coefficient }\end{array}$ \\
\hline R\&D expenditure in the public sector & $0.759^{* *}$ \\
R\&D expenditure in the business sector & $0.756^{* *}$ \\
Public-private co-publications & $0.857^{* *}$ \\
\hline
\end{tabular}

Source: own research, based on the European Innovation Scoreboard, Eurostat

The Pearson's correlation coefficient for 37 countries was calculated for the 8 -year time period. The asterisks represent significant differences $\left(p<0.01^{* *}\right)$

As can be seen from the results in Table 1, based on the correlation coefficient, it could be concluded that there is a moderate positive significant correlation between the overall Summary Innovation Index with R\&D expenditures in the public sector and the business sector as well as a high positive significant correlation between the overall Summary Innovation Index and public-private co-publications. Based on the positive correlation coefficient, it could be concluded that higher expenditures in the public and business sectors increase the Summary Innovation Index for the observed countries in Europe.

An additional observation was made as to whether there were statistically significant differences in public and business sector expenditures for the ten countries in Europe with the highest Summary Innovation Index. Paired sample t-test was used to examine the differences in relation to the dominant sector of investments in innovation. This observation pointed out differences in investments from the public and business sectors for the total period from 2012 to 2019 and then for each year individually (Table 2).

The significance of the paired sample t-test is lower than the threshold level of significance $(p=0.05)$ for all years, except for 2019. Therefore, it could be concluded that there are statistically significant differences in investments from the public and business sectors for countries with a higher Summary Innovation Index. In the countries with the highest Summary Innovation Index, more is invested from the business sector compared to the public sector (Fig. 1).

The statistically significant differences in public and business sector expenditures for the ten countries in Europe with the lowest Summary Innovation Index are investigated in this part. Paired sample $t$-test was used to examine differences in relation to the dominant sector of innovation investments for developing countries. Also, the authors found differences in investments from the public and business sectors for the total period from 2012 to 2019 , and then for each year individually (Table 3).
Table 2 Differences in investments from the public and business sectors for the countries with the highest summary innovation index from 2012 to 2019

\begin{tabular}{lllr}
\hline & $\begin{array}{l}\text { R\&D expenditure } \\
\text { in the public } \\
\text { sector }\end{array}$ & $\begin{array}{l}\text { R\&D expenditure } \\
\text { in the business } \\
\text { sector }\end{array}$ & $p$-value \\
\hline $\begin{array}{l}\text { The total period } \\
\text { from 2012 to }\end{array}$ & $0.849 \pm 0.236$ & $1.534 \pm 0.604$ & $<0.005^{* *}$ \\
2019 & & & \\
For 2012 & $0.829 \pm 0.185$ & $1.593 \pm 0.637$ & $0.001^{* *}$ \\
For 2013 & $0.84 \pm 0.172$ & $1.586 \pm 0.62$ & $0.001^{* *}$ \\
For 2014 & $0.838 \pm 0.178$ & $1.575 \pm 0.577$ & $0.001^{* *}$ \\
For 2015 & $0.851 \pm 0.176$ & $1.61 \pm 0.589$ & $0.001^{* *}$ \\
For 2016 & $0.849 \pm 0.179$ & $1.622 \pm 0.575$ & $0.001^{* *}$ \\
For 2017 & $0.853 \pm 0.189$ & $1.655 \pm 0.592$ & $0.001^{* *}$ \\
For 2018 & $0.842 \pm 0.201$ & $1.694 \pm 0.571$ & $<0.005^{* *}$ \\
For 2019 & $0.895 \pm 0.501$ & $0.939 \pm 0.517$ & 0.709 \\
\hline
\end{tabular}

Source: own research, based on the European Innovation Scoreboard, Eurostat

The asterisks represent significant differences $(p<0.01 * *)$

The significance of the paired sample $t$-test is higher than the significance level $(p<0.05)$ for all years. Therefore, it could be concluded that there are no statistically significant differences in investments from the public and business sectors for countries with the lowest Summary Innovation Index. In the countries with the lowest Summary Innovation Index, the amount of invested funds from the public and business sectors varies from year to year. Still, this difference in investments is not significant. What is evident and presented in Fig. 2 is that $R \& D$ expenditure in countries with the lowest Summary Innovation Index rises in the business sector from 2016 to 2019.

Analysing the ranking on the list, the authors found significant differences in the performances of these two groups. For example, investments from the business sector in developed countries are far greater than in the public sector (Fig. 3). The only year that stands out is 2019 . For developing countries, there is no statistical significance in the differences between the public and business sectors. Values vary year to year, but investments in $R \& D$ from both the public and business sectors are drastically less than in developed countries.

The reason why developed countries invest more in $R \& D$ than developing countries probably can be found in the analyses of the contextual indicators value within the Member states and selected third countries. Relying on fact-based reports which also explore the extent to which differences in the countries' scores in the European Innovation Scoreboard (EIS) can be explained by various socio-economic, demographic, cultural and other factors, this analysis finds that Innovation leaders 


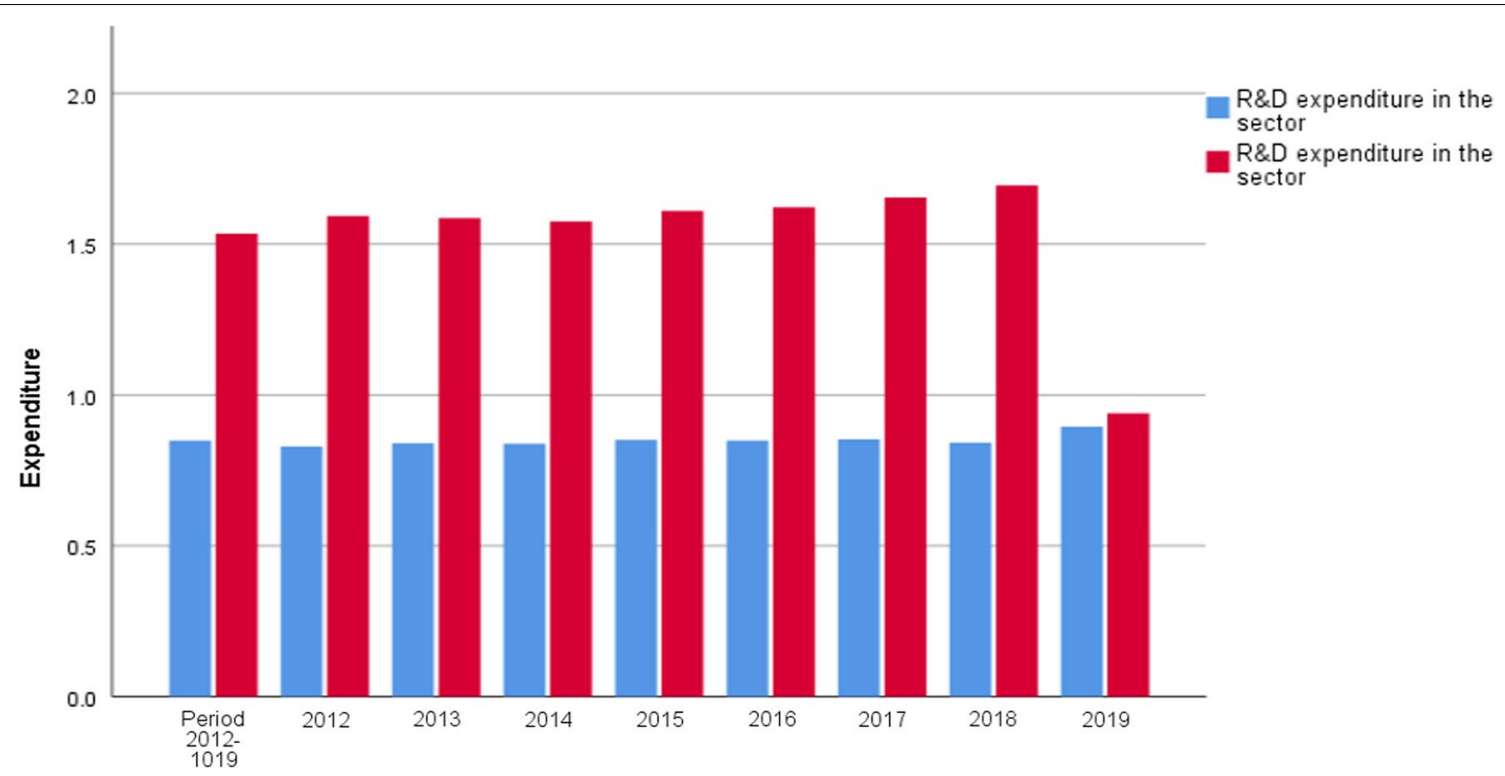

Fig. 1 R\&D expenditure for countries with the highest Summary Innovation Index. Source: own research, based on the European Innovation Scoreboard, Eurostat

Table 3 Differences in investments from the public and business sectors for developing countries with the lowest summary innovation index for the period from 2012 to 2019

\begin{tabular}{llll}
\hline & $\begin{array}{l}\text { R\&D expenditure } \\
\text { in the public } \\
\text { sector }\end{array}$ & $\begin{array}{l}\text { R\&D expenditure in } \\
\text { the business sector }\end{array}$ & $p$-value \\
\hline $\begin{array}{l}\text { The total period } \\
\text { from 2012 to }\end{array}$ & $0.362 \pm 0.138$ & $0.364 \pm 0.246$ & 0.954 \\
2019 & & & \\
For 2012 & $0.398 \pm 0.109$ & $0.337 \pm 0.204$ & 0.177 \\
For 2013 & $0.379 \pm 0.099$ & $0.337 \pm 0.236$ & 0.559 \\
For 2014 & $0.308 \pm 0.112$ & $0.353 \pm 0.238$ & 0.717 \\
For 2015 & $0.414 \pm 0.171$ & $0.379 \pm 0.261$ & 0.720 \\
For 2016 & $0.325 \pm 0.107$ & $0.377 \pm 0.243$ & 0.511 \\
For 2017 & $0.335 \pm 0.111$ & $0.398 \pm 0.261$ & 0.424 \\
For 2018 & $0.354 \pm 0.123$ & $0.435 \pm 0.31$ & 0.389 \\
For 2019 & $0.31 \pm 0.226$ & $0.324 \pm 0.251$ & 0.881 \\
\hline
\end{tabular}

Source: own research, based on the European Innovation Scoreboard, Eurostat The asterisks represent significant differences $\left(p<0.01^{* *}\right)$

use more financing of R\&D from the business sector. The right answer is how to increase investments in developing countries when a mostly elderly population remains and the impoverished state policies are missing. Another question is what will be the right model to improve investments in developing countries, both from the public and the business sector.

The regression analysis is applied to predict the Summary Innovation Index based on investments in the public sector and that for the business sector. The models obtained when using the regression analysis are presented in Figs. 4 and 5. Investments in the public sector could be used to predict the Summary Innovation Index based on the obtained statistically significant model $(p<0.0005)$. The coefficient of determination is 0.649 , and the model explains $64.9 \%$ of the total variance. Investments in the business sector could predict the Summary Innovation Index based on the obtained statistically significant model $(p<0.0005)$. The coefficient of determination is 0.625 , and the model explains $62.5 \%$ of the total variance.

The regression models in Figs. 4 and 5 show the results of the analysis on whether the Summary Innovation Index can be predicted individually based on investments in the public sector (Fig. 4) and the business sector (Fig. 5). Based on investments in the public sector, a statistically significant model is obtained $(p<0.0005)$ based on which it can be concluded that the innovation index can be predicted from investments in the public sector. The coefficient of determination is 0.649 , and based on the obtained model, $64.9 \%$ of the total sample was explained. Based on investments in the business sector, the authors obtained a statistically significant model $(p<0.0005)$ which allows them to conclude that the innovation index can be predicted from investments in the business sector. The coefficient of determination is 0.625 , and based on the obtained model, $62.5 \%$ of the total sample was explained. 


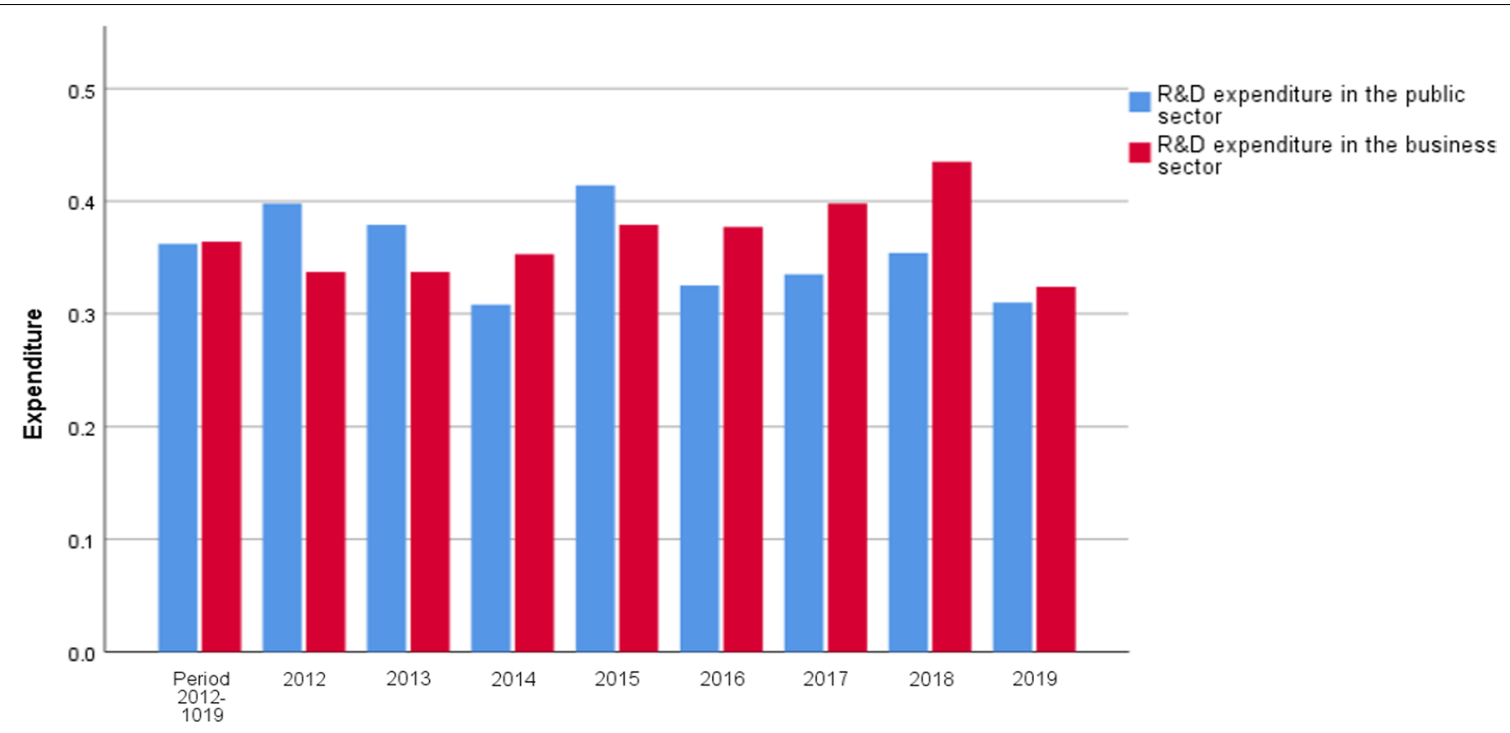

Fig. 2 R\&D expenditure for countries with the lowest Summary Innovation Index. Source: own research, based on the European Innovation Scoreboard, Eurostat

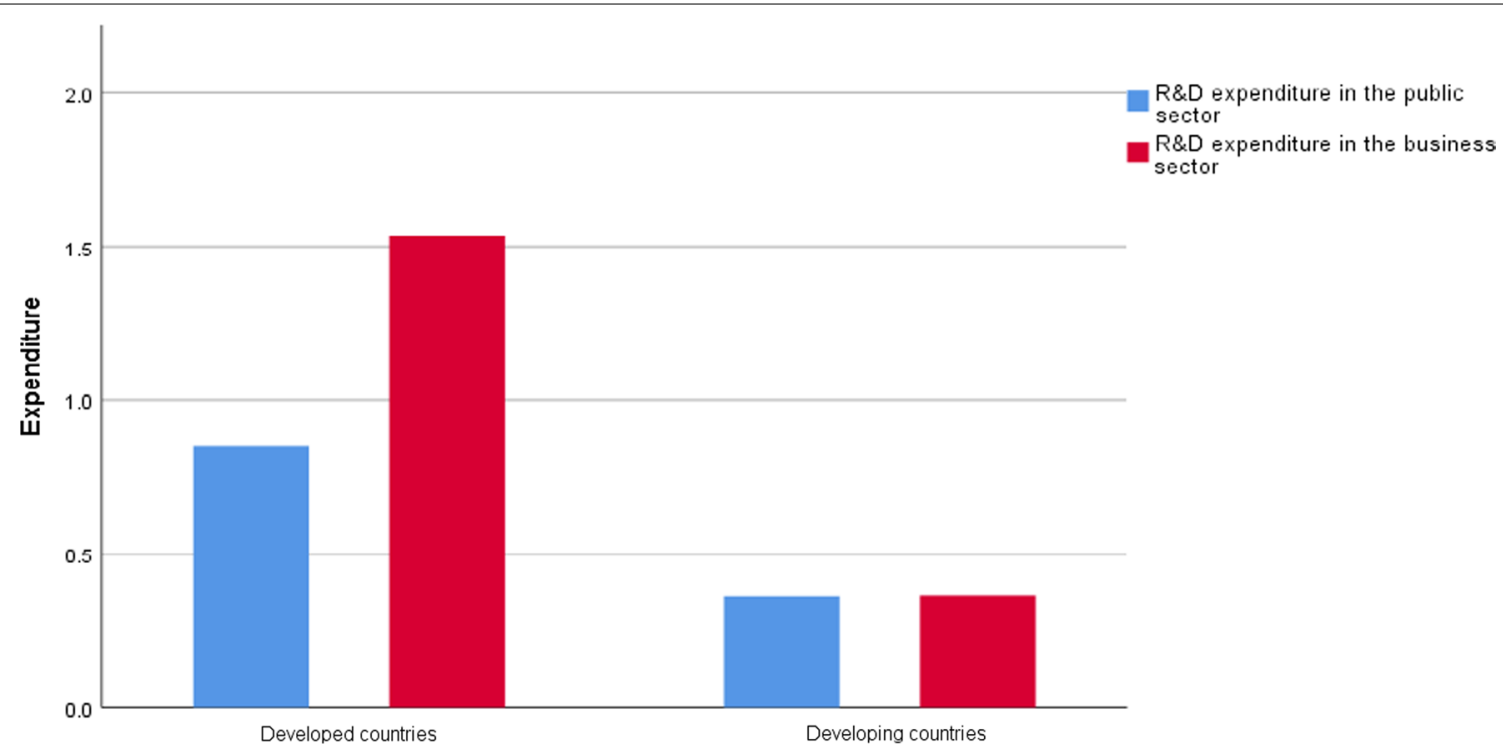

Fig. 3 R\&D expenditure for the period from 2012 to 2019 for the Summary Innovation Index. Source: own research, based on the European Innovation Scoreboard, Eurostat

In Fig. 6, by multiple regression analysis, the paper's authors predict the Summary Innovation Index based on investments in the public and business sectors. The obtained model is statistically significant $(p<0.0005)$ and could be used to predict the Summary Innovation Index on the basis of investments in the public and private sectors. The coefficient of determination is 0.748 , and the model explains $74.8 \%$ of the total variance. Thus, the obtained model is more precise than the models predicting the innovation index based on individual investments in the public and business sectors.

Essentially, the pandemic crisis has not changed the fact that the potential for breakthrough technologies and innovation continues to abound, on the contrary. Apparently, the private sector and the main $R \& D$ investors would be misguided to decrease $R \& D$ investments in their quest to secure competitiveness in the future ([32], p. 18). As the EU tends to foster green research 


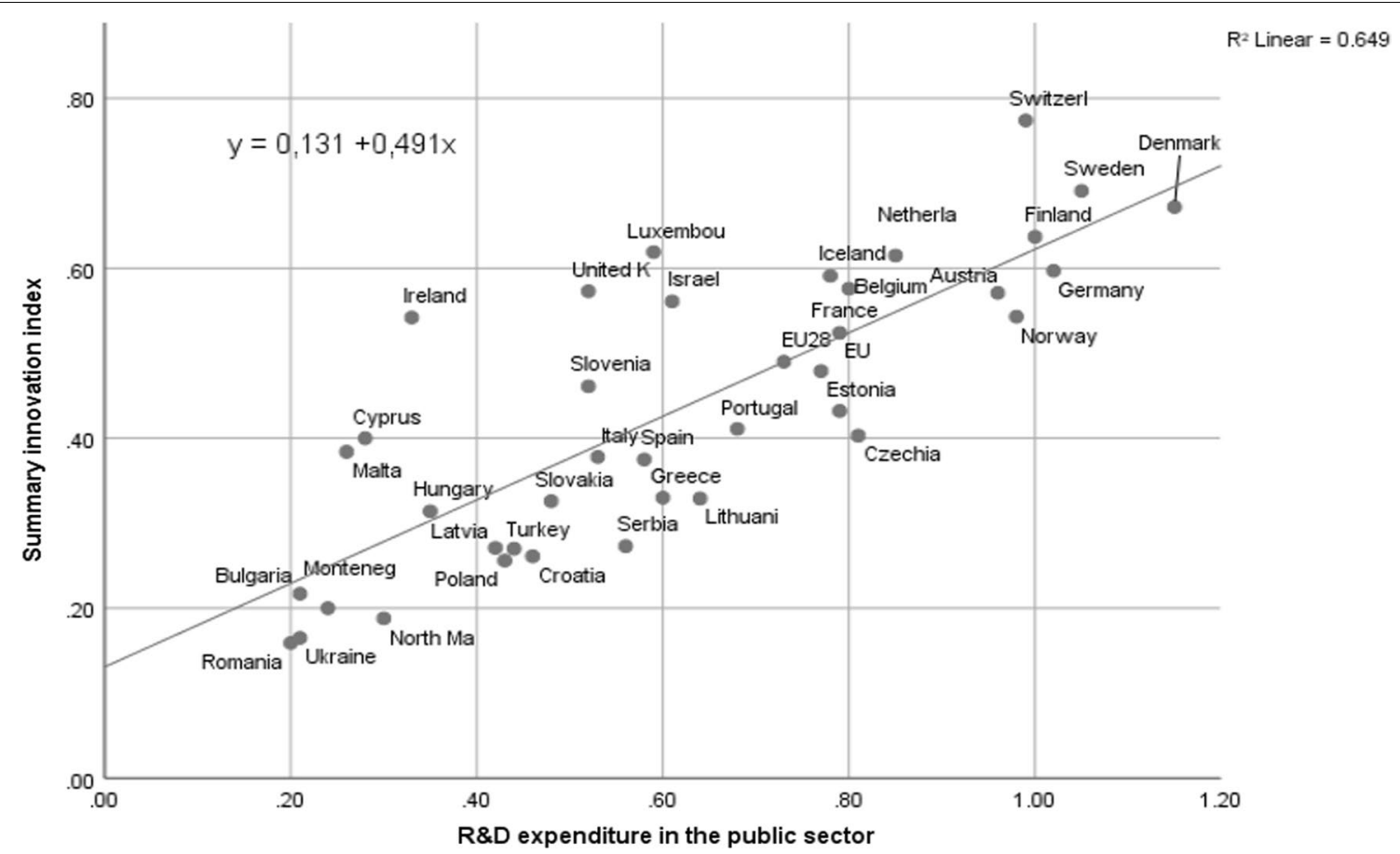

Fig. 4 The Summary Innovation Index in relation to investments in the public sector. Source: own research, based on the European Innovation Scoreboard, Eurostat

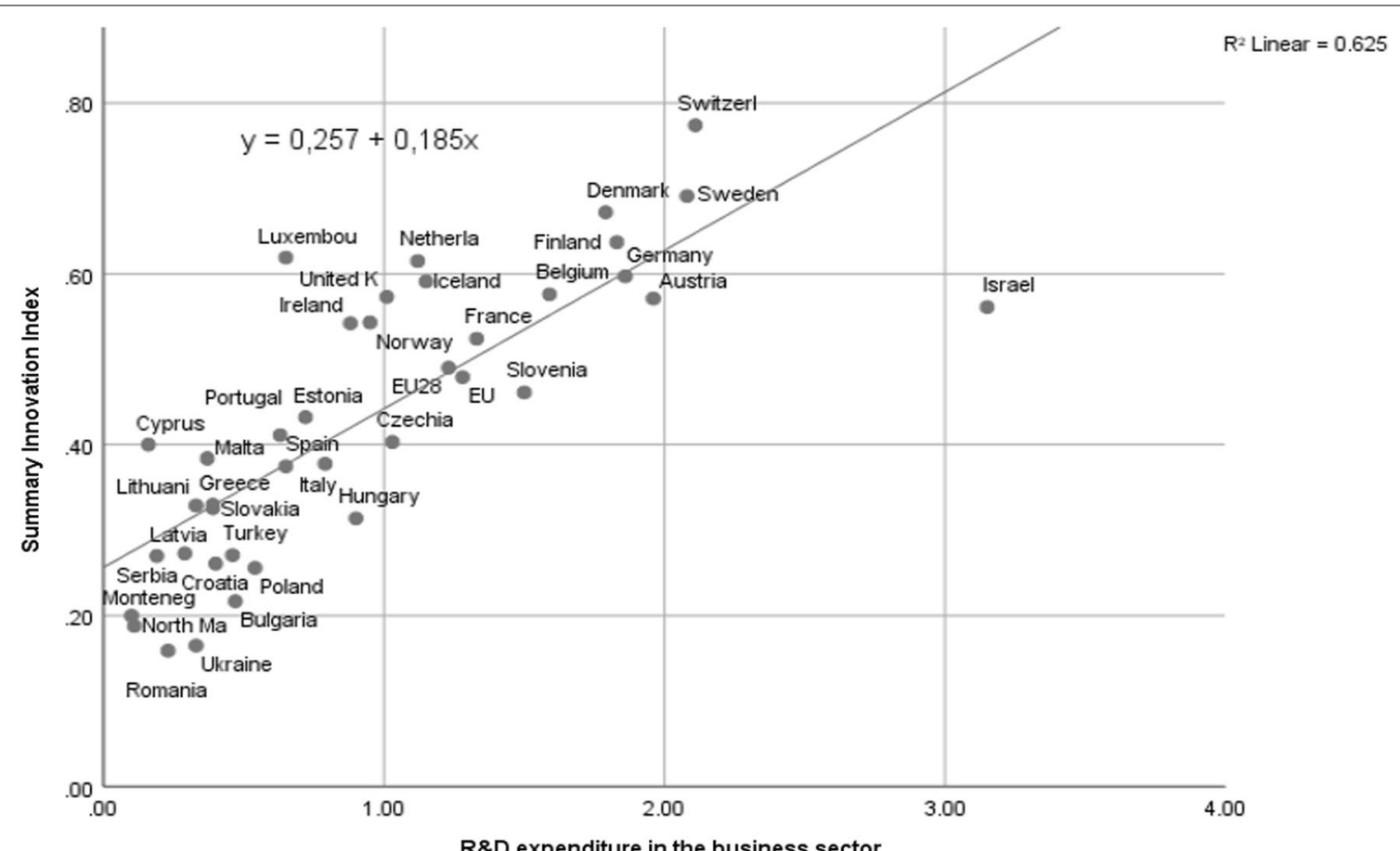

Fig. 5 The Summary Innovation Index in relation to investments in the business sector. Source: own research, based on the European Innovation Scoreboard, Eurostat 


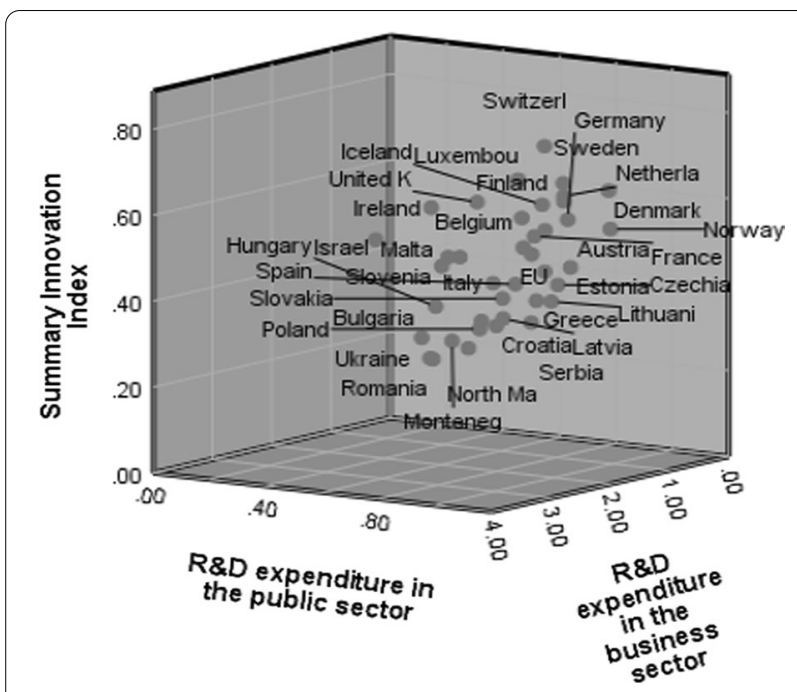

Fig. 6 The Summary Innovation Index in relation to investments in public and business sector. Source: own research, based on the European Innovation Scoreboard, Eurostat

and innovation investments, other key possible opportunity sectors, such as sustainable transport, should have to adapt faster as the quest for "clean energy" is receiving renewed interest. Furthermore, the pharmaceuticals and biotechnology sector, another top R\&D spender, is likely to experience R\&D growth boosted by the renewed and consequential focus on health R\&D. Still, whichever potentially growing sector is in the focus of this paper, sustainability and green innovation are imperative.

When the individual efforts of firms to invest in research and development to increase their performance and market success are observed, there is no conclusive evidence that more innovative firms grow more [33]. Some studies for both the developed countries' and emerging market contexts found positive evidence for this link. For the UK, Mason, Bishop, and Robinson ([34], p. 5) observed that high-growth firms innovate more and more innovative firms achieved a higher growth. A study of Brazilian firms showed that product innovations drive their sales growth, especially when combined with process innovations ([35], p. 19). A large study indicated that innovative firms create more jobs than non-innovative ones and exhibit a faster productivity growth throughout the business cycle ([36], p. 160). On the other hand, Freel and Robson [37], for Scotland and Northern England, do not found an evidence for the link between innovation and different measures of firm growth that is equally straightforward. Different narratives with regard to the question of who created a value and where that value was created and how efficient investments in research and development is-when investing from the public sector is less efficient than from the business sector-, can be found in the literature. The authors' findings support the thesis that investments in $R \& D$ are low in developing countries, while in developed EU countries, there are more investments in R\&D from the business sector for the period 2012-2019.

According to contemporary Innovation Policies, e.g. Luxembourg, as a Leading country in eco-innovation performance, with its research and innovation policy aims for stimulating competitiveness and economic growth, further boosts the performance of the public research sector and enhances the country's participation in international research programmes and collaborations. A significant peculiarity in Luxembourg's Policy for R\&D [37] is that government places particular importance onto increasing collaboration between public and private sector research through better coordination and researcher mobility. Also, their Technology and innovation policy aims to encourage companies to undertake $\mathrm{R} \& \mathrm{D}$ and innovation activities. As a third support mechanism, the government aims to develop and consolidate public scientific and technological research capacities in collaboration with the private sector. In order to contribute to the development of human scientific resources, the government strives to create a favourable environment for employment growth in the fields of science and technology that might give interesting career opportunities to researchers and facilitate their geographic and intersector mobility.

A Danish Innovation strategy will ensure that more of Denmark's knowledge and business positions of strength are translated to new jobs and growth. It will support a more goal-oriented Danish approach to creating innovative solutions to global societal challenges through three focus areas in the strategy: Innovation driven by societal challenges, More knowledge translated to value, Education as a means to increase innovation capacity. A change of culture in the education system with more focus on innovation and value creation and Green solutions of the future-strategy for investments in green research, technology, and innovation is advisable [38].

The Finnish innovation policy [39] aims to create an environment that encourages enterprises to bold innovation, renewal and international growth. Education and skills are the foundation for innovation. The aim of innovation policy is that new information generated by human inventiveness is used and deployed in all areas of society. Finnish innovation policy's characteristic of success is seen in the realistic approach in which the public sector enables and encourages innovation; where innovations are created at interfaces of different types of expertise; and renewal requires new thinking and new operating methods. 
Sweden is a creative country characterised by pioneering ideas and new ways of thinking and doing aimed at shaping our future in a global community. People in all parts of Sweden can and want to contribute to creating value for people, the economy and the environment through new or improved solutions. A strong innovation climate by 2020 will enable [40] people and actors, for being more innovative, for contribute in solutions to big societal challenges, in Sweden as well as globally. Businesses and environments are increasing their competitiveness and attract expertise, investments and cooperation partners from around the world through more innovation and value creation. Actors in the public sector and their partnership with private and civil society organisations are supplying public services of high quality and efficiency through more innovation. For Sweden, it is emphasised that these actors support the joint influence of public, private, educational, social and environmental organisations (so-called triple, quadruple, quintuple helix alliances).

According to the OECD Reviews of Innovation Policy [41], over the past two decades, Austria has become one of the most R\&D intensive economies among the OECD countries and in the world, dedicating $3.1 \%$ of its GDP to $R \& D$ in 2016, the second-highest figure in the European Union. To fully harness this R\&D capacity, Austrian innovation policy needs to put a stronger emphasis on efficiency in transforming R\&D inputs into impacts. Austria also needs to steer its research and innovation system towards leadership excellence in global markets to achieve higher impacts. This requires enhanced international attractiveness for top-level researchers and talents and a conductive environment for highly innovative enterprises. Austria could also benefit from strengthening $R \& D$ and innovation to support key transitions, such as digitalisation and Industry 4.0, and to tackle key societal challenges. The policy mix and governance arrangements should be adapted accordingly.

\section{Discussions}

Our findings support the idea of proper allocation and routing of funds into cost-effective innovations that will minimise the impact on the environment and mitigate climate change. By detecting the most efficient way to invest in eco-innovations by modelling a system to support investments in green energy and products, developed and developing countries set net zero 2050 as an EU priority. Another significant contribution of our study to the existing literature is linked with the consideration of engaging multiple actors in investing and implementing eco-innovations. In a present situation where it is questionable and empirically insufficiently confirmed how much impact eco-innovation itself has on the environment, yet every effort and research in this topic makes a huge contribution to future investment policies. Each and every part of the puzzle that is confirmed gives a clearer picture of people who make decisions at the head of the state, large corporations, local governments, small and medium enterprises, social movements, non-governmental institutions and individuals.

Limitations in applying the method in previous research, studies, and reports are reflected in insufficient data on the effects and output of eco-innovation. There are numerous efforts and initiatives that make tremendous progress and dissemination in this area. Nevertheless, primary data from the business and government sector about expenditures and investments in eco-innovation and economic and social impact in many countries are incomplete or missing. Limitations in data scope and analysis are, for example, when measuring the GDP, extracting and decompositioning the required data on investments in research and development that it cannot reflect the overall situation of people's welfare, nonmarket economic activities, the quality of the economic development, environment cost and pollution.

Many developing economies rely on high outputs supporting the growth of their own economies and are less concerned with environmental issues. Nonetheless, there is a consensus that such environmental damage should be counted against a country's GDP since it is not sustainable production and may impact future growth. One of the alternatives for measuring the impact of production and the level of eco-innovation effectiveness and eco-innovation expenditures is Green Gross Domestic Product (GGDP). The GGDP essentially penalizes a country for employing manufacturing practices that harm the environment. Such practices are seen as unsustainable, and, thus, many believe that they should be counted against a country's GDP.

Shortcomings in the treatment of secondary data sets imply that there is no statistical collection for innovative activity which abides by the logic used for other economic activity data. As a consequence, analysts rely on innovation proxies derived from administrative and survey data. However, exactly how different proxies are correlated and whether the choice amongst different proxies matters is still unclear. In the light of the innovation measurement, this paper takes another look at the relationship between different proxies of eco-innovation investment policies. In the future, the authors expect more papers dealing with the efficiency of investments in innovation in the EU, because innovations are one of the priorities of the EU Green Deal and the Recovery Plan for Europe (2021) and will be supported by the biggest EU budget ever. 


\section{Conclusions}

As Homski [42] points out that the empirical results occurred to be consistent with the research hypothesesthe public sector's share in the R\&D financing structure affects the efficiency of the R\&D sector positively, while the private sector's share affects it negatively. Such a view goes in line with assurances and evidence expressed by Mazzucato that an entrepreneurial society needs an entrepreneurial state, one that can create animal spirits in private businesses through visionary and strategic public investments, distributed across the innovation chain. Mazzucato [44] asserts that there is a need to "replace our current parasitic system with a more sustainable, symbiotic type of capitalism".

Creative industries represent activities based on individual creativity, skills, and talents that have the potential to accumulate revenue and open up new jobs through the creation and exploitation of various forms of intellectual property. Specific dimensions of innovation, viewed in a wider context, relate to the support of the development of eco-innovation and green economics or the transformation of environmental challenges into a business opportunity. As an integral part of environmental care, improving energy efficiency and resource efficiency has become an important requirement of modern business. In the following period, it is vital to build and strengthen the capacities of the national innovation system as a whole, which will effectively enable the linking of science, government and business entities and support the highly innovative SMEs, enable greater use of foreign funds available for these purposes, and encourage companies to think innovatively. It is also necessary to provide support for eco-innovation, improvement of energy efficiency and efficiency of resource use in SMEs and development of innovative entrepreneurial ventures in creative industries.

The main role and key importance of the Quadruple helix model are also confirmed in the strengthening of human resources for innovation and cooperation (recruiting staff from the economy and the public sector by universities and hiring staff and students from universities in the economy and the public sector), thus creating even more room for innovation processes. First of all, by creating regional innovation strategies, assisting all actors in the innovation process is very important to build comparative advantages, based on technological improvement-strengthening relatively weak sectors but not neglecting stronger branches. Furthermore, the tendency to foster development at different regional development levels contributes to reducing variations in regional development, which further results in increased regional and national competitiveness. In addition, through the development, implementation and monitoring of the indicators of the quadruple helix model, the analysis and synthesis of the relationship and mobility in the quadruple helix institutional sphere (at the local, national, international level), a clearer picture of the reality of measuring the efficiency of innovation processes and the use of knowledge can be made.

As mentioned in the United Nations Environment Programme [43]: Mainstreaming Eco-innovation in Sustainable Consumption and Production Policies: ecoinnovation actively contributes to decoupling economic growth from resource consumption and helps achieve the SDGs, particularly Goal 12: ensure sustainable consumption and production patterns. Through the adoption of the 2030 Agenda, the international community has recognised that current patterns of consumption and production are unsustainable and that there is a need to change consumption and production patterns systematically. Goal 12 is viewed as a cross-cutting imperative to all other commitments represented by the 2030 Agenda given its strong link to resource efficiency, consumption and lifestyle issues. In this context, the eco-innovation research in the field of cost and benefit analyse in terms of investments and effects is fully aligned with the objectives and principles of the system eco-innovation approach, supporting a range of targeted policy initiatives and recommendations. Data analysis confirmed the first hypothesis that the business sector's investments in research and development had affected the position on the list of Countries Innovative Performances of European Innovation Scoreboard. Investing in innovations and its implementation has led to huge economic growth and development, people's well-being and countries' prosperity, but also to enormous degradation of the natural environment. Today, society is struggling to push innovation that will be sustainable for human society, as well as the survival of the natural environment. The question is who will finance more radical turnover towards sustainable renewable energy resources, private or public.

On the other hand, the second hypothesis-statefunded research and development funding is dominant in lower-ranked countries-has not been confirmed, but the result has provided us with additional insight into the overall funding of R\&D in developing countries, which is extremely low in both the business and public sectors.

The proposal of a new model for investing in eco-innovations would be oriented towards predominantly higher investments from the business sector. In the case of the Summary Innovation Index, it was shown that the best performers had a structural difference compared to the less successful ones-more investments in $R \& D$ by the business sector, under the condition that the state and all public institutions provide stable legal frameworks and correctly defined intellectual property rights. 
For societies and countries in former (or not well done) transition, in developing countries, investing in the use of knowledge and innovation can regain the confidence of society in state institutions and strengthen the influence of civil society organizations (including universities, businesses, and state institutions) as the fourth pillar in the long process of building an innovative knowledge-based society and creating a stable regional and national innovation system. Examining the development of innovation capacities in Moderate and Modest Innovators countries from the Quadruple Helix perspective, the work results emphasize the necessity of understanding the context of regional/national innovation systems of countries in transition. Transition and transformation in a society induced by integration into the European Union, as well as the preparation of this process, have the main goal of assessing the impact of EU integration on reforms and implementation of superior national policies of the R\&D, new programs, actors, infrastructure, institutional framework, strengthening links in the scientific research industry, commercialization of research, internationalization, etc.

Global challenges in the information and digital sphere, health, environmental protection and all areas affected by disruptive forces can be turned into opportunities for economic growth through the implementation and joint complementary action of the main elements of the quadruple helix model. As such, the quadruple helix model can create a better way of coordination to improve productivity, production volume, and innovation. With a positive attitude towards using knowledge and innovation, scientists can create more economic, state and financial institutions interested in investing in innovation, especially in the SME sector.

As pointed out by World Intellectual Property Organisation, every crisis brings opportunities and room for creative disruption. One side effect of the current crisis has been stimulating interest in innovative solutions for health, naturally, and areas such as remote work, distance education, e-commerce, and mobility solutions. Unleashing these positive forces may well support societal goals, including reducing or reversing long-term climate change.

The shortcoming of this analysis-the unavailability of information on eco-innovation indicators in the Western Balkans countries is precisely the chance to expand and deepen the topic of investing in eco-innovation. By correctly measuring and monitoring the level of eco-innovation in the countries of the Western Balkans, it is possible to contribute to the global goal of reaching net-zero emissions by 2050. Another important challenge and necessary factor is to motivate the business sector to invest in eco-innovation. Not only because of new inflows and more sustainable products but also because of the long-term impact on our own environment and mitigation of the consequences of climate change. The Western Balkan countries should look at a good example of the Eco-IS and the Eco-Innovation Index because it complements other measurement approaches of innovativeness of EU countries and aims to promote a holistic view on economic, environmental, and social performance.

Policy recommendation for improvement of $R \& D$ Strategies for Fostering Eco-innovations in Moderate and Modest Innovation Countries should be supported by removing obstacles for precise measurement of ecoinnovation research and data collection. That means to offer a conceptual clarification of eco-innovation (developing a typology) based on an understanding of innovation dynamics, to identify and discuss the main methodological challenges in developing indicators and statistics on eco-innovation and to explore how they may be addressed, to propose possible indicators for measuring relevant aspects of Eco-innovation, taking into account data availability issues; to define future research needs for addressing these methodological challenges in developing eco-innovation indicators; and to set up guidance for the most feasible route for implementation of eco-innovation indicators on the time scale envisaged. After setting the main framework for precise measurement of cost/benefit investments in eco-innovations in practice for Moderate and Modest group of countries, to clearly underline the recommendations for Innovation policies and effects of the Recovery plan, it is preferred to encourage policymakers to take action for new legal frameworks for supporting investments in eco-innovation, new financial schemes for supporting the private sector to invest in eco-innovations and new society agendas for encouraging the local communities to take part in this eco-actions.

\section{Abbreviations}

R\&D: Research and development; Eco-IS: Eco-innovation scoreboard; EIS: European innovation scoreboard; WIPO: World Intellectual Property Organization; INSEAD: Institut Européen d'Administration des Affaires; WWF: World wide fund for nature; GDP: Gross domestic product; GGDP: Green gross domestic product; PCT: Patent cooperation treaty; RIS: Regional innovation scoreboard; TH: Triple helix; QH: Quadruple helix.

\section{Acknowledgements}

The authors acknowledge professional English language lecturer from Akademija Oxford-Novi Sad for professional English editing service.

\section{Authors' contributions}

JJ prepared concept of the study, participated in data collection, analysis and interpretation of the results. AO participated in literature collection, data interpretation and was major constructor of conclusion. AAP was major contributor in literature review and contributor in writing the manuscript. All authors participated in manuscript editing. All authors read and approved the final manuscript. 


\section{Funding}

This research (paper) has been supported by the Ministry of Education, Science and Technological Development through Project no. 451-03-9/202114/200156: "Innovative scientific and artistic research from the FTS (activity) domain".

\section{Availability of data and materials}

Not applicable.

\section{Declarations}

Ethics approval and consent to participate

Not applicable.

\section{Consent for publication}

Not applicable.

\section{Competing interests}

The authors declare that they have no competing interests.

\section{Author details}

${ }^{1}$ Faculty of Business Economics, University Educons, Vojvode Putnika 87, Sremska Kamenica, Republic of Serbia. ${ }^{2}$ Faculty of Technical Science, University of Novi Sad, Trg Dositeja Obradovića 6, Novi Sad, Republic of Serbia.

Received: 11 July 2021 Accepted: 30 November 2021

Published online: 14 December 2021

\section{References}

1. Rosenow J, Kern F (2017) EU energy innovation policy: The curious case of energy efficiency. In: Research handbook on EU energy law and policy. Edward Elgar Publishing. https://doi.org/10.4337/9781786431059.00039

2. Edquist C, Zabala-Iturriagagoitia JM, Barbero J, Zofío JL (2018) On the meaning of innovation performance: is the synthetic indicator of the Innovation Union Scoreboard flawed? Res Eval 27(3):196-211. https://doi. org/10.1093/reseval/rvy011

3. Hudec O (2015) Visegrad countries and regions: innovation performance and efficiency. Qual Innov Pros 19(2):55-72. https://doi.org/10.12776/QIP. V19|2.593

4. Nasierowski W, Arcelus FJ (2012) About efficiency of innovations: what can be learned from the innovation union scoreboard index. Procedia Soc Behav Sci 58:792-801. https://doi.org/10.1016/j.sbspro.2012.09.1057

5. European Commission (2020) European Innovation Scoreboard 2020. https://ec.europa.eu/commission/presscorner/detail/en/QANDA_20_ 1150. Accessed 10 July 2020.

6. European Commission (2021) The Eco-Innovation Scoreboard and the Eco-Innovation Index. Eco-innovation Action Plan. https://ec.europa.eu/ environment/ecoap/indicators/index_en. Accessed 10 Aug 2021.

7. Dobrzanski P (2018) Innovation expenditures efficiency in Central and Eastern European Countries. Zb rad Ekon fak Rij 36(2):827-859

8. Anderson HJ, Stejskal J (2019) Diffusion effciency of innovation among EU member states: a data envelopment analysis. Economies 7:34. https:// doi.org/10.3390/economies7020034

9. Stupak I, Mansoor M, Smith CT (2021) Conceptual framework for increasing legitimacy and trust of sustainability governance. Energ Sustain Soc 11:5. https://doi.org/10.1186/s13705-021-00280-x

10. Schilirò D (2019) Sustainability, innovation, and efficiency: a key relationship. https://www.researchgate.net/publication/334722386. https://doi. org/10.1007/978-3-030-16522-2_4

11. Gsodam P, Rauter R, Baumgartner RJ (2015) The renewable energy debate: how Austrian electric utilities are changing their business models. Energ Sustain Soc 5:28. https://doi.org/10.1186/s13705-015-0056-6

12. Katic A, Cosic I, Andjelic G, Raletic S (2012) Review of competitiveness indices that use knowledge as a criterion. Acta Polytech Hung 9(5):25-44

13. Conway E (2015) Engaging small and medium-sized enterprises (SMEs) in the low carbon agenda. Energy Sustain Soc 5:32. https://doi.org/10.1186/ s13705-015-0060-x
14. Demirel P, Kesidou E (2011) Stimulating different types of eco-innovation in the UK: government policies and firm motivations. Ecol Econ 70(8):1546-1557

15. Okanovic, A (2018) Management of competitiveness, Novi Sad, Serbia: Faculty of Technical Sciences

16. Fagerberg J, Srholec M (2008) National innovation systems, capabilities and economic development. Res Policy 37(9):1417-1435. https://doi.org/ 10.1016/j.respol.2008.06.003

17. European Commision (2018) European Innovation Scoreboard 2018 Exploratory Report C: Supplementary analyses and contextualisation of innovation performance. https://www.researchgate.net/publication/ 325285797_European_Innovation_Scoreboard_2018_Exploratory_ Report_C_Supplementary_analyses_and_contextualisation_of_innov ation_performance_data. Accessed 10 Jun 2020.

18. Furceri D, Mourougane A (2010) Structural Indicators: a critical review, OECD Journal: Economic Studies. https://www.oecd.org/economy/ growth/49850103.pdf. Accessed 24 Sep 2020.

19. Katic A, Kis T, Cosic I, Vukadinovic S, Dobrodolac Seregelj T (2015) Modelling the composite competitiveness index of the knowledge-based society. Acta Polytech Hung 12 (1): 229-249. https://doi.org/10.12700/ aph.11.10.2014.10.14

20. Škrinjaric T (2020) R\&D in Europe: sector decomposition of sources of (in) efficiency. Sustainability 12(4):1-21. https://doi.org/10.3390/su12041432

21. Solow RM (1956) A contribution to the theory of economic growth. Quart J Econ 70(1):65-94. https://doi.org/10.2307/1884513

22. Romer PM (1986) Increasing returns and long-run growth. J Polit Econ 94(5):1002-1037. https://doi.org/10.1086/261420

23. Lucas RE (1988) On the mechanics of economic development. J Monet Econ 22(1):3-42. https://doi.org/10.1016/0304-3932(88)90168-7

24. Cortright J (2001) New Growth Theory, Technology and Learning: A Practitioner's Guide, Reviews of Economic Development Literature and Practice, No. 4, EDA, U.S. Economic Development Administration. from https://e-tcs.org/wp-content/uploads/2012/10/Cortright-nueva_teoria_ del_crecimiento.pdf. Accessed 27 May 2020.

25. Cavallini S, Soldi R, Friedl J, Volpe, M (2016) Using the Quadruple Helix Approach to Accelerate the Transfer of Research and Innovation Results to Regional Growth, European Union, Committee of the Regions. https:// op.europa.eu/en/publication-detail/-/publication/6e54c161-36a9-11e6a825-01aa75ed71a1. Accessed 27 May 2020

26. Ilina I, Streltsova E, Platova M, Borodin A, Yakovenko I (2019) The impact of public investment on the competitiveness of the Russian R \& D sector. Int J Mech Eng Technol (IJMET) 10(1):1128-1140

27. Krozer Y (2017) Innovative offices for smarter cities, including energy use and energy-related carbon dioxide emissions. Energy Sustain Soc 7:6. https://doi.org/10.1186/s13705-017-0104-5

28. Castiglione C, Infante D, Smirnova J (2015) Environment and economic growth: is the rule of law the go-between? The case of highincome countries. Energ Sustain Soc 5:26. https://doi.org/10.1186/ s13705-015-0054-8

29. Mazzucato M (2014) The entrepreneurial state: debunking public vs. private sector. Anthem Press, Myths, London

30. Lundvall BA, Johnson B, Andersen ES, Dalum B (2002) National systems of production, innovation and competence building. Res Policy 31(2):213231. https://doi.org/10.1016/S0048-7333(01)00137-8

31. Reid A, Rivera L, Muscio A (2015) An empirical test of the regional innovation paradox: can smart specialisation overcome the paradox in Central and Eastern Europe? J Econ Policy Reform 18(2):153-171. https://doi.org/ 10.1080/17487870.2015.1013545

32. WIPO (2020) World intellectual property indicators 2020. World Intellectual Property Organization, Geneva

33. Demirel P, Mazzucato M (2009) Survey of the Literature on Innovation and Economic Performance, FINNOV Discussion Paper, http://oro.open. ac.uk/28551/1/Finnov_D2.1.pdf. Accessed 15 Sep 2020

34. Mason G, Bishop K, Robinson C (2009) Business growth and innovation: the wider impact of rapidly growing firms in UK city-regions. London: NESTA. http://www.niesr.ac.uk/pdf/190509_94959.pdf. Accessed 23 Jan 2020

35. Goedhuys M, Veugelers R (2008) Innovation strategies, process and product innovations and growth: company-level evidence from Brazil, Flanders: KULeuven, 1-27 
36. Peters B, Dachs B, D"unser M, Hud M, K"ohler C, Rammer C (2014) Firm Growth, Innovation and the Business Cycle. Number No. 110577. Mannheim: ZEW-Center for European Economic Research. https://www.econs tor.eu/bitstream/10419/110577/1/797733930.pdf. Accessed 20 June 2020.

37. Freel M, Robson PJA (2004) Small firm innovation, growth and performance-evidence from Scotland and northern England. Int Small Bus J 22(6):561-575. https://doi.org/10.1177/026624260404741

38. Le Gouvernment de Grand-Duche de Luxembourgh. Research and innovation policy. http://www.innovation.public.lu/en/decouvrir/politique/ politics/index.html. Accessed 10 Sept 2021

39. Ministry of Higher Education and Science of Denmark. Green solutions of the future - Strategy for investments in green research, technology, and innovation. https://ufm.dk/en/publications/2020/green-solutions-of-thefuture-strategy-for-investments-in-green-research-technology-and-innov ation. Accessed 10 Sept 2021

40. Ministry of Economic Affairs and Employment of Finland. Innovation Policy. https://tem.fi/en/innovation-policy. Accessed 10 Sept 2021.

41. Government Officies of Sweden. The Swedish Innovation Strategy. https://www.government.se/contentassets/cbc9485d5a3446729632 25858118273b/the-swedish-innovation-strategy. Accessed 10 Sept 2021

42. OECD Reviews of Innovation Policy: Austria 2018. https://www.oecd. org/publications/oecd-reviews-of-innovation-policy-austria-2018-97892 64309470-en.htm. Accessed 10 Sept 2021

43. Homski A (2019) Efficiency of the R\&D sector in the EU states. Does the source of funds matter? Res Papers Econ Finance 3(2):37-44. https://doi. org/10.18559/ref.2018.2.4

44. Mazzucato M (2016) An Entrepreneurial Society Needs an Entrepreneurial State, Harvard Business Review. https://hbr.org/2016/10/an-entreprene urial-society-needs-an-entrepreneurial-state. Accessed 15 Sep 2020

45. United Nations Environment Programme (2017) Mainstreaming Ecoinnovation in Sustainable Consumption and Production Policies. http:// unep.ecoinnovation.org/wp-content/uploads/2018/03/UNEP_157-Mains treaming-ecolnnovation_web.pdf. Accessed 10 Sept 2021

\section{Publisher's Note}

Springer Nature remains neutral with regard to jurisdictional claims in published maps and institutional affiliations.

Ready to submit your research? Choose BMC and benefit from:

- fast, convenient online submission

- thorough peer review by experienced researchers in your field

- rapid publication on acceptance

- support for research data, including large and complex data types

- gold Open Access which fosters wider collaboration and increased citations

- maximum visibility for your research: over 100M website views per year

At BMC, research is always in progress.

Learn more biomedcentral.com/submissions 